\title{
Specially protected natural areas of the Russian Far North
}

\author{
Valentina Okmyanskaya ${ }^{1, *}$ \\ ${ }^{1}$ Federal State Budget Educational Institution of Higher Education Industrial University of Tyumen, \\ 625000, Tyumen, Russia
}

\begin{abstract}
An important measure of the legal protection of the economic and social interests of small groups of indigenous people is the allocation of territories of traditional nature management. When it comes to territories of traditional environmental management of indigenous people as specially protected natural territories, the regime of environmental management should be environmentally reasonable, socially acceptable and costeffective. However, the realization of these conditions is tough. The task is to direct the process of development of the territories of traditional environmental management in an environmentally safe course, to try to integrate these territories into various spheres of life of indigenous people, especially in the northern regions, until they are roughly integrated exclusively into the production sphere. The difficulties of the legal plan are caused by the inconsistency of the sectoral federal and regional legislation, the protracted procedure for the development of the status, regime and, especially, the territorial boundaries of the territories of traditional environmental management.
\end{abstract}

\section{Introduction}

Because of the process of democratization of society, changes in the social and economic situation, large-scale development of natural resources, especially in the northern regions of Russia, the issues of ensuring and developing small groups of indigenous people, the territories of their residence and economic activity are becoming more and more important priorities of state policy. In addition, due to the continuous growth of anthropogenic influence, an urgent task is the preservation and development of specially protected natural territories of different levels, the legal regime of which theoretically should reduce the anthropogenic impact of mining companies on the vulnerable ecosystem of the North. In cases of the creation of territories of traditional nature, management should pursue two goals - the preservation of nature and the creation of the acceptable life conditions to indigenous people [1].

However, at present days, on the one hand, the legislative base is developing very intensively, hypothetically declaring the possibility of preserving unique natural complexes and objects, traditional way of life and traditional environmental management of indigenous people, significant budget funds are allocated to support traditional activities of

\footnotetext{
* Corresponding author: okmjanskajavm@tyuiu.ru
} 
these people (reindeer herding, fish and fur trades, national crafts, etc.). On the other hand, the fuel and energy complex is actively developing on the territory of the Far North, while the economic attractiveness of the fields and the corresponding land plots conflicts with the requirements for the protection of the environment and the interests of the indigenous people living in these territories [2].

Due to the fact that the territory of the Far North is rich with natural complexes with environmental, scientific, cultural and aesthetic values, often within the boundaries of specially protected natural areas, oil and gas industry is carried out, which leads to a decrease in the number of rare animals and birds, disturbance of the natural landscape, soil pollution, destruction of vegetation cover, reduction of deer pasture area, etc. First of all, these circumstances are related to the fact that in recent years, changes in environmental protection legislation have occurred, which do not always have a positive effect on the development of the activities of the indigenous minorities. At the same time, at the process of the organization of the territories of traditional nature management the problems presented on a picture 1 should be solved. However, the intensive economic use of natural resources is still a top priority.

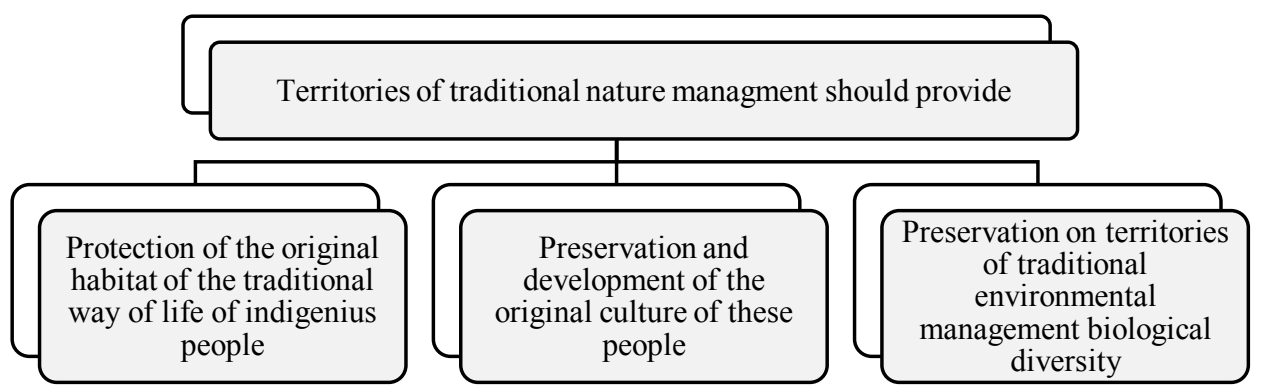

Fig. 1. Tasks of the organization of territories of traditional environmental management.

Many scientists, environmentalists, public figures say that the law of the Russian Federation of 21.02.1992 № 2395-1 “On subsoil” prevails over laws regulating relations in the organization, protection and use of specially protected natural territories, environmental protection, environmental safety, as well as regulatory acts protecting the rights of indigenous people and restricting economic activities within the boundaries of traditional environmental management areas.

These facts are confirmed by the adoption in 2013 of the Federal law of 28.12.2013 № 406 "On amendments to the Federal law «On specially protected natural territories" and certain legislative acts of the Russian Federation". Within the new provisions of this law, the territories of traditional nature use are no longer specially protected and do not belong to the lands of specially protected natural territories. On the basis of article 6 of the Federal law of 28.12.2013 № 406 "On amendments to the Federal law "On specially protected natural territories" and certain legislative acts of the Russian Federation", the territories of traditional nature use were excluded from the composition of environmental protection lands (Article 95 of the Land code of the Russian Federation of 25.10.2001 №. 136), which are part of the lands of specially protected natural territories [3].

Also, a significant negative consequence of the adoption of amendments to the Federal law "On specially protected natural territories" of 14.03.1995 № 33 in terms of reducing the categories of specially protected natural territories is the fact that today's documentation of this project for the construction, reconstruction of buildings, structures, including those intended for the extraction of natural resources, within the boundaries of the territories of traditional environmental management is not a subject to state environmental impact 
assessment in accordance with articles 11 - 12 Federal law of 23.11.1995 № 174 "On ecological expertise". Lack of environmental impact assessment of project documentation leads to uncontrolled development and intensive economic development of territories, which serve to maintain traditional environmental management and traditional lifestyles of small groups of indigenous people of the North, which prevents the implementation of their rights, preserved in the constitution of the Russian Federation and relevant federal laws [4].

Based on the previous comments, let us consider the main changes in the legislation about the territories of traditional environmental management in Table 1.

Table 1. Review of changes in legislation.

\begin{tabular}{|c|c|c|}
\hline Legal act & Amendments & Base \\
\hline $\begin{array}{c}\text { The federal law of } \\
\text { 14.03.1995 № } 33 \text { “On } \\
\text { specially protected natural } \\
\text { territories” }\end{array}$ & $\begin{array}{l}\text { Territories of traditional nature } \\
\text { use are excluded from the } \\
\text { categories of specially protected } \\
\text { natural territories }\end{array}$ & $\begin{array}{c}\text { Article } 1 \text { of the Federal law } \\
\text { of 28.12.2013 № } 406 \text { “On } \\
\text { amendments to the Federal } \\
\text { law“ On specially protected } \\
\text { natural territories “ }\end{array}$ \\
\hline $\begin{array}{l}\text { Federal Law of } 07.05 .2001 \\
\text { No. } 49 \text { "On the territories of } \\
\text { traditional nature use of the } \\
\text { indigenous minorities of the } \\
\text { North, Siberia and the Far } \\
\text { East of the Russian } \\
\text { Federation" }\end{array}$ & $\begin{array}{l}\text { Everywhere the words "natural" } \\
\text { are excluded in the context of } \\
\text { these territories to specially } \\
\text { protected natural territories }\end{array}$ & $\begin{array}{c}\text { Article } 5 \text { of the Federal law } \\
\text { of 28.12.2013 № } 406 \text { “On } \\
\text { amendments to the Federal } \\
\text { law“ On specially protected } \\
\text { natural territories “ }\end{array}$ \\
\hline $\begin{array}{c}\text { Land code of the Russian } \\
\text { Federation of } 25.10 .2001 \text { No. } \\
136\end{array}$ & $\begin{array}{l}\text { From article } 95 \text {, the territories } \\
\text { of traditional nature use of } \\
\text { small groups of indigenous } \\
\text { people are excluded people of } \\
\text { the North, Siberia and the Far } \\
\text { East of the Russian Federation }\end{array}$ & $\begin{array}{c}\text { Article } 6 \text { of the Federal law } \\
\text { of } 28.12 .2013 \text { № } 406 \text { “On } \\
\text { amendments to the Federal } \\
\text { law“ On specially protected } \\
\text { natural territories “ }\end{array}$ \\
\hline
\end{tabular}

Due to the fact that places of traditional nature use are no longer the lands of specially protected natural territories, the land plots located within their borders are no longer subject to restriction, which leads to the development of economic activity on these lands, which leads the loss of unique properties and characteristics of such lands. The land resources of the Far North are recovering very slowly after those developments, and natural complexes can lose their valuable and unique features forever. However, if the territories of traditional nature use are located within the boundaries of specially protected natural territories of other categories presented in Figure 2, the effect of the amendments will not apply.

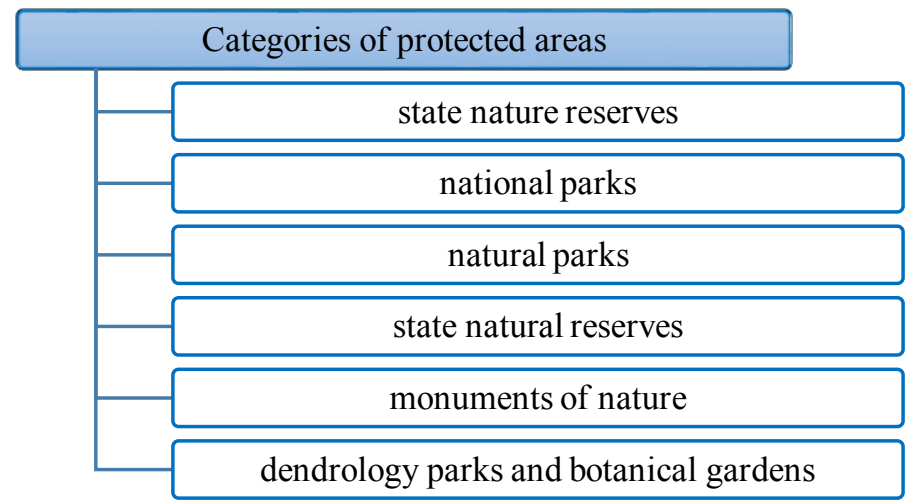

Fig. 2. Categories of Protected Areas. 
It is worth to mention, that despite the fact that the residences and household activity of indigenous people of the North are excluded from the number of specially protected natural territories, in the Federal law of 07.05.2001 No. 49 "On the territories of traditional nature management of the indigenous minorities of the North, Siberia and the far East The Russian Federation" such territories equals to specially protected territories established for the conduct of traditional environmental management and the traditional way of life of such people, which in our opinion, created $t$ is some contradiction in the legislation on the definition of the status of these territories [5].

You can also see the general features of the legal regime of the territories of traditional environmental management and specially protected natural territories. In accordance with Article 39.10 of the Land code of the Russian Federation of 25.10.2001 No. 136, land plots provided to subjects of traditional nature use and traditional economic activities for a free use. And in case of withdrawal of the above land plots and natural objects located within the boundaries of the territories of traditional nature use, equivalent areas are provided for state and municipal needs, individuals and communities of indigenous people, and damages caused by such withdrawal are compensated [6].

As already noted above, the places of traditional nature management located in the far North are of great interest, because, on the one hand, the northern territories are a platform for the development of the domestic economy, on the other, the fragile northern ecosystem and the territories of traditional habitats and traditional economic development activities of small groups of indigenous people. One of the subjects within whose borders more than $20 \%$ of the territory is occupied by tribal lands in which small people of the North — the Khanty, the Mansi and the Nenets - who constitute $2 \%$ of the total population lead a traditional way of life, are the Khanty-Mansiysk Autonomous Okrug - Ugra.

In the field of organization, protection and use of specially protected natural areas of regional importance, the Duma of the Khanty-Mansiysk Autonomous Okrug-Ugra adopted a law of 29.03.2018 No. 34-oz "On the regulation of individual relations in the field of organization, protection and use of specially protected natural areas of regional importance Khanty-Mansiysk Autonomous Okrug - Ugra", which establishes the following categories of valuable territories:

1) Natural parks;

2) State natural reserves;

3) Monuments of nature;

4) Dendrological parks and botanical gardens [7].

Also, in order to develop a system of specially protected natural areas of regional importance in the Khanty-Mansiysk Autonomous Okrug - Ugra, a Concept was developed, approved by the Okrug Government Decree No. 245-p of July 12, 2013 "On the concept of development and functioning of the system of specially protected natural territories Okrug Ugra for the period up to 2020".

Based on the analysis of the above-mentioned regional regulatory acts of the territory of traditional nature use are not considered in detail among the specially protected natural territories of the autonomous region.

In accordance with the Decree of the Government of the Autonomous Okrug of 10.04.2002 No. 192-p "On the territories of traditional nature management", the patrimonial lands formed earlier (since 1998) in the territory of the Autonomous Region are referred to the territories of traditional nature management of regional importance. However, at present, the concept of "patrimonial ground" has been dismissed, since the Statute on the status of patrimonial ground in the Khanty-Mansiysk Autonomous Area of 07.02.1992 has lost its force, which leads to the disappearance of this concept from the scientific and applied lexicon. 
Today, in the Khanty-Mansiysk Autonomous Okrug, 475 territories of traditional nature use with a total area of 12668423 hectares $(23.7 \%$ of the area of the okrug) registered in all districts. As already noted, often the traditional places of residence of the indigenous people of the North are located within the boundaries of specially protected natural territories. One of the proper examples of the inclusion of traditional nature use areas in the categories of unique natural objects is the Numto Regional Nature Park, located on the territory of the Beloyarsky District of the Khanty-Mansiysk Autonomous Okrug (Figure 3).

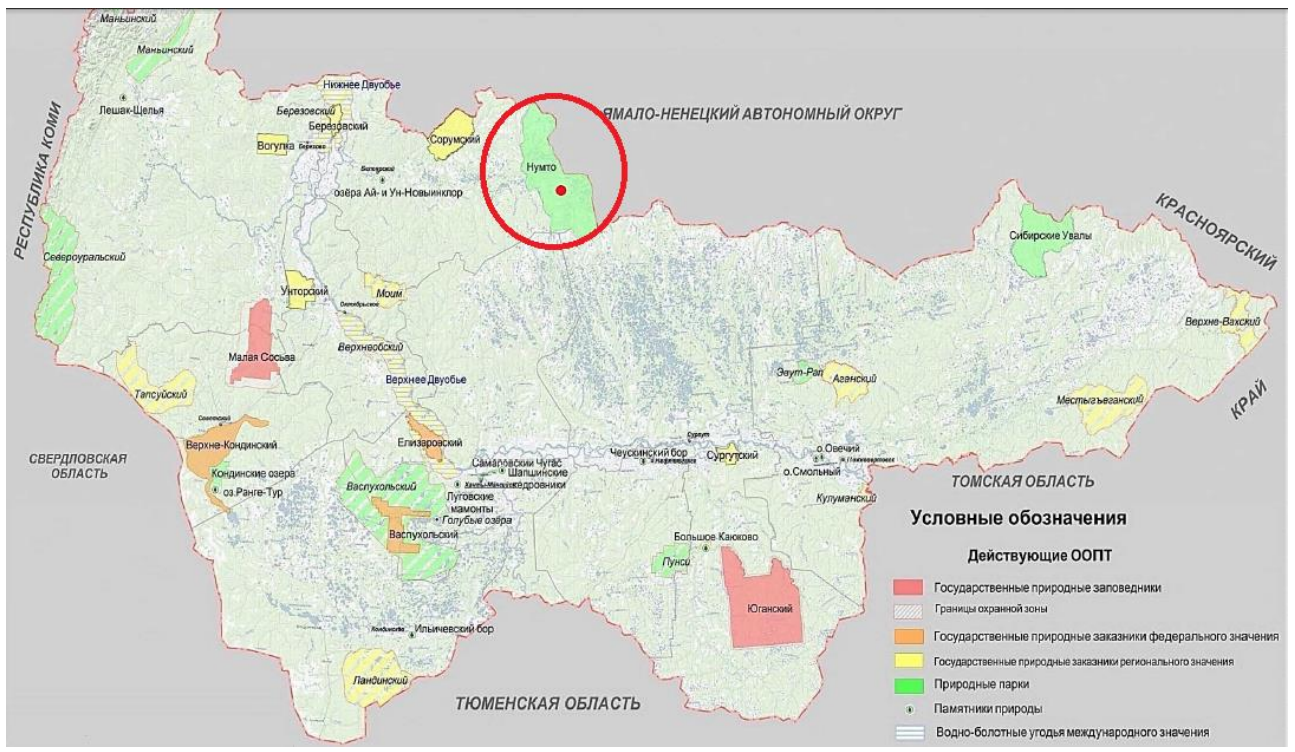

Fig. 3. Geographical location of the natural park "Numto".

The park is located in the center of the West Siberian Plain and includes three zones tundra, forest tundra and taiga. Located on the border of the Yamalo-Nenets and KhantyMansiysk Autonomous Okrug, it occupies a special position in geography, ecology, and ethnography of the Tyumen North.

A brief description of the park is given in Table 2 .

Table 2. Characteristics of the natural park "Numto".

\begin{tabular}{|c|c|c|}
\hline № & Characteristic & Description \\
\hline 1 & Category & Natural park \\
\hline 2 & Value & Regional meaning \\
\hline 3 & Square & 556664 hectares \\
\hline 4 & Land category & The lands of the forest \\
\hline 5 & $\begin{array}{l}\text { Data from the } \\
\text { public cadastral } \\
\text { map }\end{array}$ & $\begin{array}{l}\text { Cadastral number: } \\
\text { 86: 06: 0030201: } 12 \\
\text { Status: } \\
\text { Previously counted } \\
\text { Address: } \\
\text { Khanty-Mansi Autonomous Area - Ugra, Beloyarsky District, } \\
\text { Numto Natural Park } \\
\text { Land category: } \\
\text { Forest land } \\
\text { Type of ownership: } \\
\text { state } \\
\text { Cadastral value: } \\
\text { 599,091,510.00 rubles }\end{array}$ \\
\hline
\end{tabular}




\begin{tabular}{|c|c|c|}
\hline & & $\begin{array}{l}\text { Declared area: } \\
7,217,970,000 \text { sq. M. m } \\
\text { Permitted use: } \\
\text { For other forestry facilities } \\
\text { according to the document: } \\
\text { to accommodate a natural park } \\
\text { Date of registration: } \\
\text { 09.05.2005 } \\
\text { Date of change of information in the State Real Estate Cadaster: } \\
\text { 08.09.2017 }\end{array}$ \\
\hline 6 & Date of creation & 28.01 .1997 \\
\hline 7 & $\begin{array}{l}\text { Purpose of } \\
\text { creation }\end{array}$ & $\begin{array}{l}\text { Preservation of the natural and historical complex of the Kazym } \\
\text { River and Lake Numto, unique natural, historical, ethnographic } \\
\text { complexes, protection of the places of residence and economic } \\
\text { activities of the indigenous minorities of the North }\end{array}$ \\
\hline 8 & Tasks & $\begin{array}{l}\text { 1. Maintenance of poorly stable biosensors at the junction of } \\
\text { landscape zones of tundra, forest-tundra, taiga; } \\
\text { 2. Protection of valuable areas of wetland complexes as habitats of } \\
\text { migratory near-water birds; } \\
\text { 3. Conservation of water resources, rare plant and animal species; } \\
\text { migration routes of migratory birds and seasonal migrations of } \\
\text { artiodactyls (elk, wild northern forest deer); } \\
\text { 4. Preservation of cultural heritage sites; } \\
\text { 5. Maintaining and restoring the natural living conditions of the } \\
\text { indigenous people of the North; } \\
\text { 6. Implementation of environmental monitoring; } \\
\text { 7. Creating conditions for regulated tourism and recreation; } \\
\text { 8. Environmental education of the population. }\end{array}$ \\
\hline 9 & $\begin{array}{l}\text { Regulatory basis } \\
\text { of operation }\end{array}$ & $\begin{array}{l}\text { 1. Resolution of the Governor of the Khanty-Mansiysk Autonomous } \\
\text { Okrug No. } 71 \text { dated January } 28,1997 \text { "On the creation of a natural } \\
\text { park of district value Numto in the Khanty-Mansiysk Autonomous } \\
\text { Okrug. } \\
\text { 2. Resolution of the Government of the Khanty-Mansiysk } \\
\text { Autonomous Okrug-Ugra dated 10.28.2016 415-p "On the } \\
\text { Regulation on the Numto Nature Park". } \\
\text { 3. Order of the Department of State Property Management of the } \\
\text { Khanty-Mansiysk Autonomous Okrug-Ugra of January 24, 2012 06- } \\
87 \text { / 12-0 "On approval of the charter of the institution" } \\
\text { 4. Decree of the Department of State Property Management of the } \\
\text { Khanty-Mansiysk Autonomous Okrug-Ugra dated August 21, } 2013 \\
\text { No. 13-p-1765 "On Amending the Charter of the Establishment" }\end{array}$ \\
\hline 10 & $\begin{array}{l}\text { Departmental } \\
\text { subordination }\end{array}$ & $\begin{array}{l}\text { Department of Natural Resources and Non-Primary Sector of the } \\
\text { Economy of the Khanty-Mansiysk Autonomous Okrug - Ugra }\end{array}$ \\
\hline 11 & $\begin{array}{l}\text { Legal entities } \\
\text { responsible for } \\
\text { the protection } \\
\text { and operation of } \\
\text { the park }\end{array}$ & $\begin{array}{l}\text { Budgetary institution of the Khanty-Mansiysk Autonomous Okrug - } \\
\text { Ugra "Natural Park" Numto " }\end{array}$ \\
\hline 12 & Natural features & $\begin{array}{l}\text { 1. Located in three natural zones - tundra, forest-tundra and taiga; } \\
2 \text {. The basis of the park is Lake Numto, which is located in the } \\
\text { center of wetlands with unique flora and fauna; } \\
\text { 3. The climate is characterized by a harsh long winter with long } \\
\text { frosts and steady snow cover; } \\
\text { 4. The soil cover is represented mainly by marsh soils; } \\
\text { 5. Most of the park is a flat marshy lake-alluvial plain, characterized } \\
\text { by a large number of lakes. }\end{array}$ \\
\hline 13 & Historical & 1. The presence of monuments of archaeological history, which are \\
\hline
\end{tabular}




\begin{tabular}{|l|l|l|}
\hline & $\begin{array}{l}\text { cultural heritage } \\
\text { of the park }\end{array}$ & $\begin{array}{l}\text { left by the population who lived here for 4-5 thousand years. } \\
\text { 2. The presence of about 65 monuments of ethnic culture (sacred } \\
\text { sites, burial complexes, reflecting the peculiarities of religious } \\
\text { beliefs of indigenous people). }\end{array}$ \\
\hline 14 & $\begin{array}{l}\text { Main protected } \\
\text { species of flora } \\
\text { and fauna }\end{array}$ & $\begin{array}{l}\text { 1.18 rare plant species, 4 of which are included in the report "rare } \\
\text { and endangered plants of Siberia" (tripartite bed-bed, heart-shaped } \\
\text { cache, water silo leaf, likopodiella poured), 4 are listed in the Red } \\
\text { Book of KhMAO (baranets, heart-shaped cache, likopodiella poured } \\
\text { in), 5 require special attention (water silo leaf, small capsule, three- } \\
\text { cut Badian, Hebrides fingernail, Lapland buttercup); } \\
\text { 2. The park is home to about 20 species of mammals (common lynx, } \\
\text { wolverine, river otter, sable, columns, etc.), about 150 species of } \\
\text { birds (squirrel, bean goose, red-breasted brant, small swan, tundra } \\
\text { swan, common turpan, herring gull, gyrfalcon, peregrine falcon, } \\
\text { etc.) 3 species of amphibians, two reptiles, about 10 species of fish } \\
\text { (cheese, cheek, ide, nelma, taimen, etc.) }\end{array}$ \\
\hline 15 & $\begin{array}{l}\text { 1. Reserve zone } \\
\text { 2. Conservation zone } \\
\text { 3. Zone of traditional extensive environmental management } \\
\text { Park Zoning }\end{array}$ \\
& $\begin{array}{l}\text { 4. Recreation area } \\
\text { 5. Cultural heritage protection zone } \\
\text { 6. Economic Zone }\end{array}$ \\
\hline
\end{tabular}

The natural park «Numto» is a specially protected natural area, within which are concentrated rare representatives of flora and fauna, which are listed in the Red List of the International Union for Conservation of Nature and Natural Resources, the Red Book of the Russian Federation, the Khanty-Mansi Autonomous Area, cultural heritage, as well as a unique body of water - lake Numto, unique areas of natural landscapes. In particular, within the boundaries of the natural park there are territories of traditional nature use, where the people of the Siberian North live - Khanty and Nenets of the forest (Figure 4) [8]. 


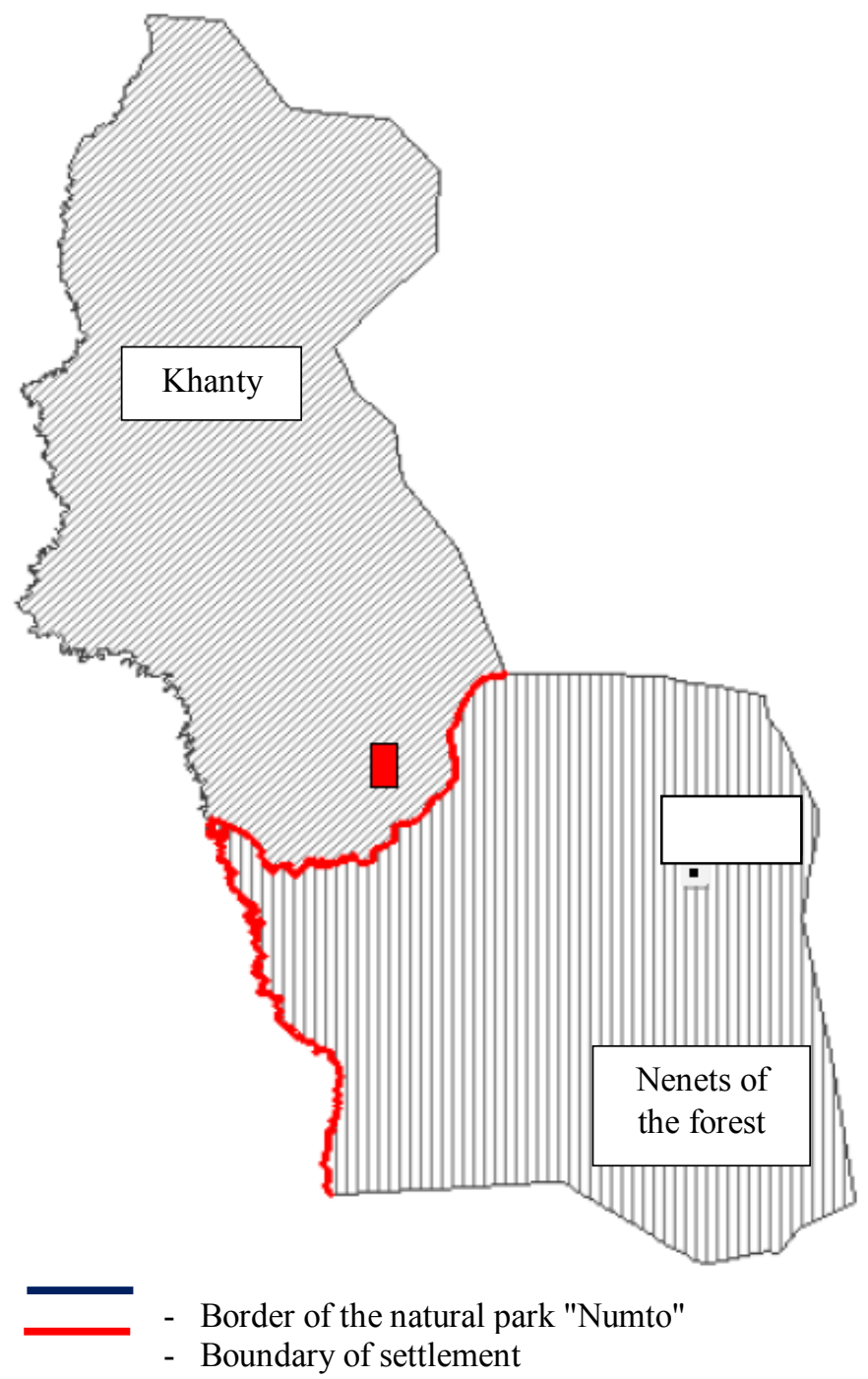

Fig. 4. Settlement of indigenous people of the North in the Numto Park.

Due to rich hydrocarbon reserves, which have been found in the territory of this specially protected natural area, they are currently being developed in the economic zone of the park, which occupies most of the area of the natural complex. Park zoning is shown in Figure 5.

Subsoil use on the territory of a natural park carried out in the manner established by the legislation of the Russian Federation and the autonomous region, taking into account the peculiarities of zoning and the established regime of special protection in its territory.

Figure 6 presents a fragment of the scheme reflecting the location of production facilities within the boundaries of the Numto Park. 


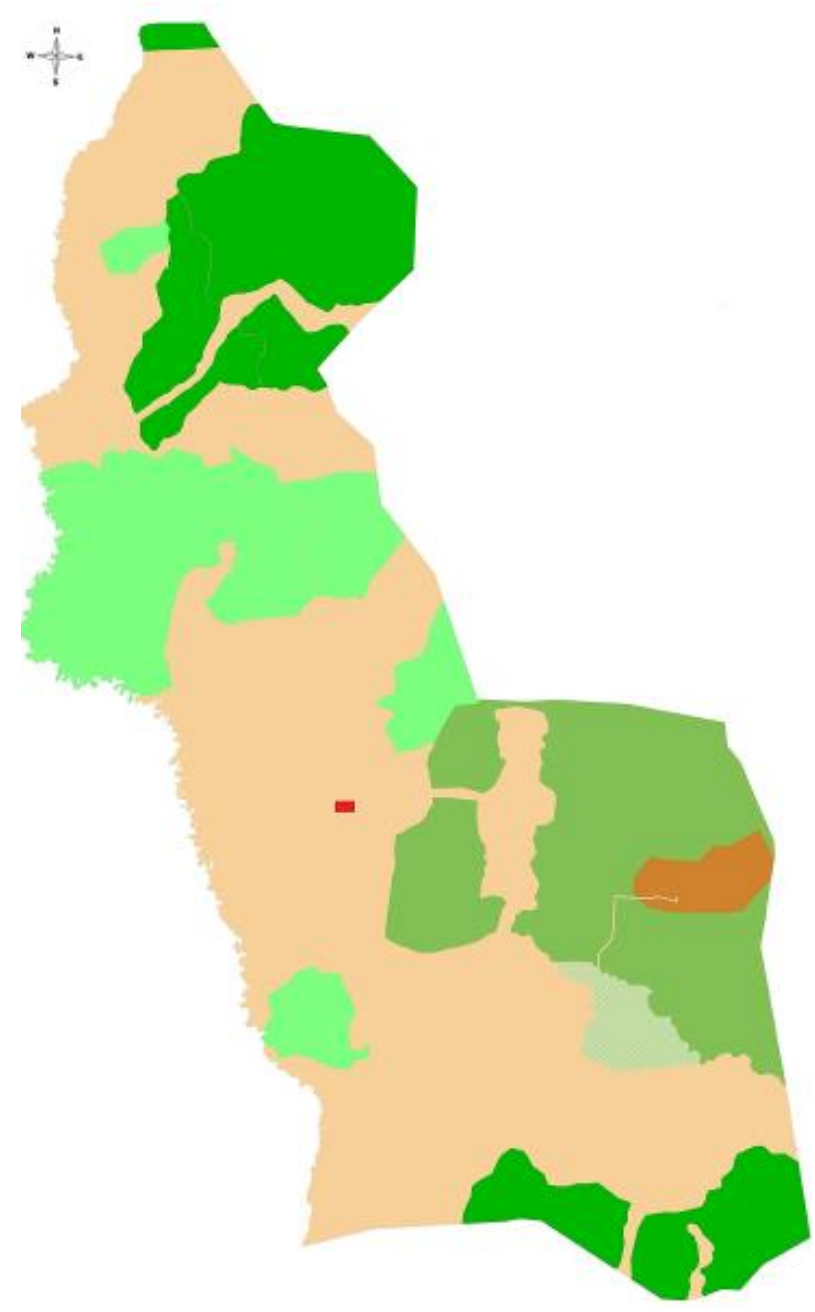

Legend

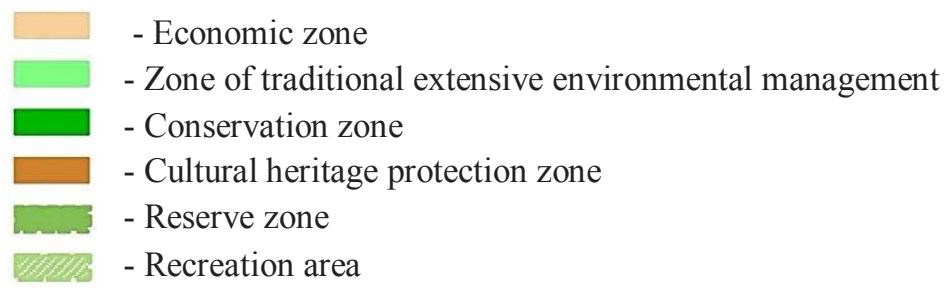

Fig. 5. Zoning of the natural park "Numto". 


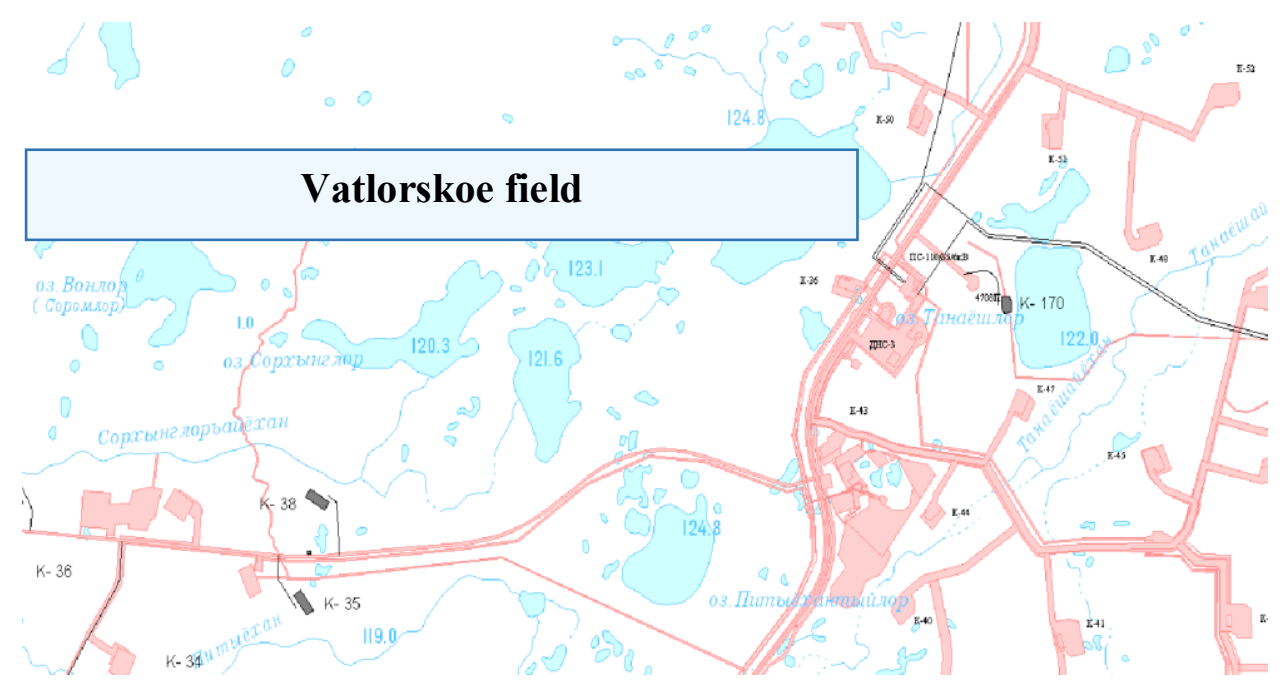

Fig. 6. Fragment of the scheme of production facilities located on the territory of the Numto Natural Park.

In the economic area of the park "Numto" the following activities are provided:

1) Traditional nature use;

2) Preservation of cultural heritage sites;

3) Environmental monitoring;

4) Carrying out environmental, biotechnical and fire prevention measures, forest management and land management;

5) Geological study of the subsoil, exploration and extraction of minerals, including common minerals, timber harvesting, as well as for sanitary felling, placement of linear objects.

It is important to note that in October 2016, the Government of the Khanty-Mansiysk Autonomous Okrug-Ugra changed the "Numto" zoning, which allowed for the extraction of natural resources in wetlands, despite the fact that wetlands around the world are considered as one of the most important conditions for maintaining the quality of life, and sometimes the very existence of the indigenous people of a particular country, including being a source of fish and animals, especially for the local population.

The branch of the Greenpeace International Non-Profit Organization, in February 2016, sent to the Department of natural resources and the non-extractive sector of the economy of the Khanty-Mansiysk Autonomous Okrug - Ugra on the possibility of adjusting the boundaries of functional zones, and as a result of comprehensive studies it was concluded, that the change of zoning is inadmissible, permitting exploration and mining in the areas currently assigned to the wetland area of the park. However, as already mentioned, the functional zoning of the park was changed, as a result of which wetlands became a place of extraction of hydrocarbon raw materials, which confirms the fact of contradiction between the legislation in the field of mining, use and protection of the subsoil over environmental standards, including legislative acts on specially protected natural territories.

Because of anthropogenic activities associated with the extraction of hydrocarbon raw materials, the following negative consequences observed in the park:

1) Air pollution by emissions of pollutants (Nitrogen dioxide, carbon (soot), sulfur dioxide, carbon oxide, manganese and its compounds, gaseous fluorides, poorly soluble, inorganic dust, toluene, etc.);

2) Vibration, electromagnetic exposure, noise pollution;

3) Violation of land cover; 
4) The seizure of natural objects as habitats of hunting and commercial species of animals and birds for the construction of production facilities, which leads to a decrease in populations and a decrease in species diversity;

5) Pollution of surface, groundwater, as a result of the allocation of places for domestic and industrial wastewater during construction, operation of oil and gas production facilities, the emergence of unauthorized territories for waste accumulation;

6) Contamination of the territory with waste of I-IV hazard classes;

7) Violation of the natural topography;

8) change in the hydrological regime of water bodies;

9) Reducing the area of land suitable for maintaining the traditional nature management of the Khanty and forest Nenets, which ensure their livelihoods.

Currently, the urgent issue is to ensure sustainable social-economic development of the territories inhabited by small groups of indigenous people, a significant increase in their standard of living and improvement of the entire life-support system on the first steps of rational nature management, technical and technological improvement of traditional industries, social services, culture and life.

\section{Conclusions}

Considering this, we can draw the following conclusions:

1. Currently, the large-scale development of natural resources leads to the infringement of the rights and interests of small groups of indigenous people, whose ethnic identity is directly related to traditional nature management, traditional way of life. To resolve this problem, it is necessary to improve the allocation procedure and model of legal registration of traditional environmental management areas, the development of compensation procedures and compensatory measures, mandatory and strict regulation of the behavior of personnel of mining companies in the places of residence and traditional economic activities of indigenous people.

2. The exclusion of the territories of traditional nature use from the categories of specially protected natural territories leads to the disturbance of the natural environment, and limits the traditional nature use by the small groups of indigenous people. It is necessary, in our opinion, to ensure the legal regime of the territories of traditional environmental management with standards that exclude or substantially limit the use of land plots in the territories of traditional residence and traditional economic activity for survey works or their withdrawal for state and municipal needs.

3. The possibility of ecological zoning of specially protected natural areas, providing for the allocation of various types of zones - from completely forbidden economic activities to regulated intensive development with maximum impact on the natural environment of the region, leads to the expansion of economic activities within their borders and creates the basis for countless conflicts between oil and gas companies public authorities, local authorities, environmental organizations, and also by population.

\section{References}

1. A.A. Tranin, Territories of traditional environmental management of indigenous peoples of the Russian north (problems and prospects) 7 (2010)

2. I.N. Kustysheva, Development of methods of land protection under the objects oil and gas complex with regional peculiarities Far north. 3 (2016) 
3. Federal

Law

№

406 , http://www.consultant.ru/cons/cgi/online.cgi?req=doc\&base $=$ LAW\&n=168138\&fld $=1$ $34 \& d s t=100141,0 \& \mathrm{rnd}=0.7609202955810568 \# 07747734947818912$

4. Federal law №174, http://www.consultant.ru/document/cons_doc_LAW_8515/

5. Federal law №49, http://www.consultant.ru/cons/cgi/online.cgi?req=doc\&base $=$ LAW\&n=173601\&fld=1 $34 \& \mathrm{dst}=100056,0 \& \mathrm{rnd}=0.4560734709224388 \# 05813471873548395$

6. Land code of the Russian Foderation №136, http://www.consultant.ru/document/cons_doc_LAW_33773/

7. Law of 29.03.2018 No. 34-oz, http://docs.cntd.ru/document/543549604

8. Cadastral report on specially protected natural area natural Park regional significance "Numto», http://oopt.aari.ru/ 